\title{
Влияние бета-каротинсодержащего препарата на морфо-биохимические показатели крови цыплят-бройлеров
}

Злепкин В.А., доктор сельскохозяйственных наук, доцент

Злепкин Д.А., доктор биологических наук, профессор

Рудаков А.В., аспирант

Волгоградский государственный аграрный университет

Аннотация: В научно-хозяйственном опыте на 4 группах цыплят-бройлеров кросса «Росс-308» (50 голов 6 каждой, с 1 по 41 дни жизни) изучено блияние бета-каротинсодержащего препарата на морфо-биохимические показатели крови. Цыплята контрольной группы не получали препарат; цыплята опытных групп I-ІІІ получали с тем же рационом 2,0; 2,5 и 3,0 л препарата на 1 m комбикорма. Установлено, что содержание эритроцитов 6 крови бройлеров I, II и III опытных групп увеличилось на 5,57; 8,70 и 6,63\%, а гемоглобина - на 2,24; 5,57 и 3,18\% соответственно по сравнению с аналогами контрольной группы. Отмечено также незначительное увеличение содержания лейкоцитов в крови бройлеров опытных групп (на 0, $15 ; 0,46$ и 0,27\% по срабнению с контролем). Увеличение концентрации эритроцитов и гемоглобина является положительным физиологическим признаком, определяющим бысокий уровень обменных процессов, проходящих 6 организме цыплят-бройлеров, и обуславливается прямой взаимосвязью морфо-биохимических показателей крови с приростом живой массы.

Ключебые слова: иыллята-бройлеры, эритроциты, гемоглобин, лейкоциты, общий белок В сыборотке крови, кальций, фосфор.

Введение. Одним из важнейших элементов организма животных и птицы является кровь. Она является внутренней средой, посредством которой клетки тела получают все необходимые вещества из внешней среды, и куда выделяют многочисленные продукты своего обмена. Ее количественный и качественный состав во многом определяет интенсивность обмена веществ и связанных с ним процессов роста, развития и продуктивности [1].
Кровь является средой, необходимой для организации взаимосвязи между собой окислительно-восстановительных процессов, уровня метаболизма, роста и развития организма. Имея относительно постоянный состав, она создает условия для переноса питательных веществ к органам и тканям, участвует в синтезе структурных тканей, продуктов обмена [3].

Как показали многие исследования, морфологический и биохи- мический состав крови птицы зависят, в первую очередь, от генетических факторов: вида, возраста, породы, пола, физиологического состояния, направления продуктивности и др. Но на состав крови значительное влияние оказывают внешние условия, и, в первую очередь, условия кормления и содержания. Из факторов внешнего воздействия наиболее существенными являются условия кормления. Это, в основном, тип кормления, уровень кормления и полноцен- 
ность кормового рациона. Морфологический и биохимический состав крови в значительной степени меняется от того, какие питательные вещества, в каких количествах и соотношениях попадают в кровяное русло и разносятся по органам, тканям и клеткам организма $[5,9,10]$.

Одним из основных путей реализации продуктивного потенциала птицы является улучшение качества комбикормов и повышение их биологической полноценности за счет включения различных биологически активных кормовых препаратов и добавок.

Цель наших исследований изучить влияние использования бета-каротинсодержащего препарата «Каролин» на морфобиохимические показатели крови цыплят-бройлеров кросса «Росс308».

Материал и методика исследований. Для изучения влияния разного количества бетакаротинсо-держащего препарата на продуктивные качества и физиологическое состояние цыплятбройлеров кросса «Росс-308» в условиях $\mathrm{AO}$ «Птицефабрика Краснодонская» Иловлинского района Волгоградской области был проведен научно-хозяйственный опыт. По методу аналогов были сформированы 4 группы суточных цыплят-бройлеров (контрольная и 3 опытных) по 50 голов в каж- дой.

В кормлении цыплят-бройлеров были использованы полнорационные комбикорма: ПК-0-1417 (с 1 по 7 день); ПК-2-16-17 (с 8 по 14 день); ПК-5-31-17 (с 15 по 28 день); ПК-6-36-1 7 (с 29 по 34 день) и ПК-7-34-17 (с 35 по 41 день). Рецепты комбикормов отличались тем, что в опытные партии дополнительно вводили разное количество бета-каротинсодержащего препарата.

Контрольная группа цыплятбройлеров, согласно фазам выращивания, получала полнорационные комбикорма (ПК), І опытная группа - ПК, в состав которых вводили 2,0 л бета-каротинсодержащего препарата на 1 т комбикорма, II опытная группа - ПК с 2,5 л бета-каротинсодержащего препарата, III опытная группа - ПК с 3,0 л препарата на 1 т комбикормa.

Условия содержания, параметры микроклимата, фронт кормления и поения для цыплятбройлеров всех групп были одинаковыми.

Для изучения морфобиохимических показателей крови у цыплят был произведен забор крови.

\section{Результаты исследований и} их обсуждение. Содержание эритроцитов и гемоглобина в крови цыплят-бройлеров опытных групп I, II и ІІІ было выше, чем у ана- логов контрольной группы, соответственно на 0,16 (5,57\%); 0,25 $(8,71 \%) ; 0,19^{*} 10^{12} /$ л $(6,62 \%)$ и на 2, 15 (2,24\%); 4,97 (5, 17\%); 3,06 г/л $(3,18 \%)$.

По данным показателям установлено преимущество II опытной группы, цыплята которой превосходили по содержанию эритроцитов в крови аналогов I и III опытных групп соответственно на 0,09 $(2,97 \%)$ и $0,06 * 10^{12} / л \quad(1,96 \%)$, гемоглобина - на 2,82 (2,87\%) и 1,91 г/л (1,93\%).

Хорошо известно, что главной функцией лейкоцитов является защита организма от инородных тел, появляющихся в крови и тканях. Лейкоциты могут проходить сквозь тонкую стенку капилляров и свободно продвигаться в различные участки тела, поэтому их еще называют блуждающими клетками. При встрече с микроорганизмами или отмершей клеткой лейкоциты выпускают ложноножки, обхватывают инородное тело, поглощают его и с помощью ферментов переваривают в своей протоплазме [2].

Необходимо отметить, что в крови цыплят-бройлеров отмечено незначительное изменение уровня лейкоцитов: в крови цыплят-бройлеров опытных групп I-III он увеличился по сравнению саналогами контрольной группы соответственно на 0,04 (0,15\%); 0,12 $(0,46 \%)$ и $0,07^{*} 10^{9} /$ л $(0,27 \%)$. 
Ряд ученых и практиков проявляют огромный интерес к составу крови. Однако поиски связи морфологического состава крови с продуктивными качествами показали, что он лишь косвенно связан с продуктивностью. Более тесная связь с продуктивностью просматривается у биохимического состава крови.

Определение общего белка в сыворотке крови дает представление об уровне белкового питания и помогает диагностировать гепатопатию и нефропатию. Отклонения уровня белка от нормы свидетельствуют о глубоких нарушениях обмена веществ в организме [1].

В наших исследованиях с введением в комбикорма цыплятбройлеров разного количества бета-каротинсодержащего препарата наблюдалось увеличение концентрации общего белка в сыворотке крови во всех опытных группах, с превышением показателя контрольной группы на 0,65 $(1,55 \%) ; 1,86(4,43 \%)$ и 1,06 г/л $(2,52 \%)$ соответственно группам IIII.

Преимущество по данному показателю имели цыплята II опытной группы, они превосходили аналогов I и III опытных групп на 1,21 (2,84\%) и 0,80 г/л (1,86\%) соответственно.

Содержание общего белка в сыворотке крови зависит главным образом от синтеза и распада двух основных белковых фракций - альбуминов и глобулинов.

В исследованиях установлено, что абсолютное содержание альбуминов в сыворотке крови цыплят-бройлеров опытных групп I-ІІІ было выше в сравнении с контрольной группой на 0,43 (2,71\%); $1,28(8,06 \%)$ и 0,80 г/л $(5,04 \%)$ соответственно.

Преимущество по абсолютному содержанию альбуминовой фракции в сыворотке крови имели цыплята-бройлеры II опытной группы, превосходившие аналогов из I и III опытных групп соответственно на 0,85 (5,52\%) и 0,48 г/л $(2,28 \%)$.

Увеличение концентрации альбуминов в сыворотке крови цыплят-бройлеров является резервом для повышения использования в организме пластического материала в синтезе белков тканей. Очевидно, альбуминовая фракция является наиболее мелкодисперсной, легко мобилизуется для синтеза тканевых белков растущего организма. Это согласуется с мнением ряда исследователей, которые считают, что содержание альбуминов в сыворотке крови характеризует уровень белкового обмена в организме вообще. Повышение содержания альбуминовой фракции напрямую связано с продуктивностью [6].

Абсолютное содержание глобулинов в сыворотке крови цып- лят-бройлеров опытных групп I-III было выше на 0,22 (0,84\%); 0,58 $(2,22 \%)$ и 0,26 г/л $(0,99 \%)$. Альбумин-глобулиновый коэффициент (А/Г) показывает интенсивность обменных процессов в организме птицы. Цыплята опытных групп по данному показателю превосходили аналогов контрольной группы соответственно на 1,$64 ; 4,92$ и $3,28 \%$.

Таким образом, включение в рационы цыплят-бройлеров опытных групп разного количества бета-каротинсодержащего препарата способствовало активизации белкового обмена в организме, что подтверждается увеличением прироста их живой массы.

Важным показателем минерального обмена у птицы является содержание в сыворотке крови кальция и фосфора. Минеральные вещества рациона находятся в состоянии постоянного обмена с минеральными веществами внутренней среды организма. Кальций - макроэлемент, необходимый для построения скелета, клюва, когтей, он способствует свертыванию крови, стимулирует работу сердца, повышает устойчивость к инфекционным заболеваниям. Кальций в организме депонируется преимущественно в костях (до 98\%). Дефицит кальция в организме птицы снижает аппетит, задерживает рост, ухудшает состояние оперения [8]. 
Наиболее высокое содержание кальция было в сыворотке крови цыплят-бройлеров II опытной группы, превосходивших аналогов контрольной и I и ІІІ опытных групп на 0,05 (1,68\%); 0, 10 (3,37\%) и 0,07 ммоль/л (2,02\%) соответственно.

Фосфор - макроэлемент, который способствует всасыванию в кишечнике глюкозы и жирных кислот, играет важную роль в обмене и транспорте жиров, белков, углеводов, входит в состав всех тканей организма. Около 85\% всего фосфора находится в скелете. При недостатке фосфора у птицы снижается аппетит, задерживается рост, уменьшается масса костей, повышается смертность молодняка, нарушается подвижность суставов [7].

По содержанию фосфора в сыворотке крови цыплятабройлеры опытных групп I-III превосходили аналогов контрольной группы на 0,03 (1,54\%); 0,09 (4,62\%) и 0,05 ммоль/л (2,56\%) соответственно.

Заключение. Полученные нами результаты изучения морфологических и биохимических показателей крови цыплят-бройлеров, получавших разные дозы бетакаротинсодержащего препарата, свидетельствуют о том, что гематологические показатели цыплят были в пределах физиологической нормы.
Использование в рационах цыплят-бройлеров опытных групп бета-каротинсодержащего препарата способствовало улучшению морфо-биохимического состава крови. Это положительно отразилось на обменных процессах и на интенсивности роста цыплятбройлеров опытных групп. Наиболее эффективной оказалась доза препарата 2,5 л/т корма.

\section{Литература}

1. Злепкин Д.А. Морфобиохимический состав крови цыплятбройлеров и их сохранность, как критерий оценки биологической активности триптофана / Д.А. Злепкин, А.Ф. Злепкин, В.А. Злепкин, Р.А. Гашук // Известия Нижневолжского агроуниверситетского комплекса. - 2016. №4(44). - C. 141-146.

2. Злепкин Д.А. Морфобиохимические показатели крови цыплят-бройлеров при использовании в рационах рыжикового жмыха взамен соевого шрота / Д.А. Злепкин, Т.С. Колобова // Научные основы стратегии развития АПК и сельских территорий в условиях ВТО: Мат.. Междунар. науч.-практ. конф. Волгоград, 2013. - С. 189-191.

3. Злепкин Д.А. Физиологическое состояние и продуктивность цыплятбройлеров при включении в их рацион биологически активных добавок // Известия Нижневолжского агроуниверситетского комплекса. - 2015. - №1 (37). - C. 142-147.

4. Комарова 3.Б. Гематологические показатели цыплят-бройлеров при использовании в их рационах микроэлементов органического происхождения / З.Б. Комарова, Д.Н. Ножник, С.М. Иванов, П.С. Андреев // Новые подходы, принципы и механизмы повышения эффективности производства и переработки с.-х. продукции: Мат. междунар. науч.-практ. конф., 5-6 июня 2014 г. - Волгоград, 2014. - С. 119-121.

5. Комарова З.Б. Влияние кормовых добавок «Нутойод» и «Нутосел» в рационах кур-несушек на гематологические показатели крови / З.Б. Комарова, С.М. Иванов, Д.Н. Ножник, С.П. Косинов // Инновационные технологии в производстве и переработке с.-х. продукции в условиях ВТО: Мат. междунар. науч.-практ. конф., г. Волгоград, 4-5 июня 2013 г.; под ред. В.Н. Хромовой. - Волгоград: ВолгГТУ, 2013. - С. 164-167.

6. Злепкин А.Ф. Морфологический и биохимический состав крови цыплятбройлеров при введении в рацион биологически активных препаратов / А.Ф. Злепкин, В.В. Саломатин, В.А. Злепкин, В.О. Паршкова // Птицеводство.-2019. - №2. - C. 30-34.

7. Zimmermann J.A. Effects of probiotics in swines growth performance: A metaanalysis of randomized controlled trials / J.A. Zimmermann, M.L. Fusari, E. Rossler et al. // Anim. Feed Sci. Technol. - 2016. - V. 219. - P. 280-293.

8. Yu Y.-J. Effects of whey peptide extract on the growth of probiotics and gut microbiota / Y.-J. Yu, M. Amorim, C. Marques, C. Calhau, M. Pintado // J. 
Funct. Foods. - 2016. - V. 21. - P. 507516.

9. Liu H. Effects of Lactobacillus brevis preparation on growth performance, fecal microflora and serum profile in weaned pigs / H. Liu, H.F. Ji, D.Y. Zhang,

S.X. Wang et al. // Livestock Sci. - 2015. -

V. 78. - P. 251-254.

Для контакта с авторами:

Злепкин Виктор Александрович
E-mail: vzlepkin@mail.ru

Злепкин Дмитрий Александрович

E-mail: dzlepkin@mail.ru

Рудаков Алексей Витальевич

E-mail: kliv11@rambler.ru

The Effects of Dietary Beta-Carotene Containing Preparation on Morphological and Biochemical Blood Parameters in Broiler Chicks

Zlepkin V.A., Zlepkin D.A., Rudakov A.V.

Volgograd State Agrarian University

Summary: The effects of a dietary beta-carotene containing preparation on morphological and biochemical blood parameters atment was fed diets without the preparation; experimental treatments I; II and III were fed the same diets suppwere studied on 4 treatments of Ross-308 broiler chicks (50 birds per treatment, from 1 to 41 days of age). Control trelemented with 2.0; 2.5 and $3.0 \mathrm{~L}$ of the preparation per 1 t of feed. It was found that RBC concentration in experimental treatments I-III was higher by $5.57 ; 8.70$ and $6.63 \%$, hemoglobin by $2.24 ; 5.57$ and $3.18 \%$, respectively, in compare to control; the insignificant increase in the concentration of total leukocytes was also found (by 0.15 ; 0.46 and $0.27 \%$ ). The increases in the concentrations of RBC and hemoglobin can be regarded as beneficial physiological signs evidencing high level of the metabolism; these morphological blood parameters are directly correlated with the productive performance (weight gains) in broilers.

Key words: broiler chicks, red blood cells (RBC), hemoglobin, leukocytes, total protein in serum, calcium, phosphorus.

ОТРАСЛЕВЫЕ НОВОСТИ

\section{Алтайский край стал оснобным экспортером мяса птиц,ы 6 Казахстан}

Алтайский край увеличил отгрузки продукции птицеводства.

В минувием году местные производители отправили иностранным заказчикам более 650 тонн продукции на сумму 1550 тыс. долларов.

Основные рынки сбыта - Казахстан, Вьетнам и КНР. Главный поставщик - предприятие «Алтайский бройлер».

Всего 6 ушедшем году 6 крае произвели свыше 68 тыс. тонн мяса и субпродуктов птицы. Относительно 2018 года эти объемы Выросли почти на 4\%. Тренд прошлого года - рост спроса на продукцию птицеводства, которая стала пользоваться больщей популярностью и как основа для диетического питания, так и повседневного потребления.

В текущем году мяса птиць 8 алтайском регионе станет больще: мощности «Алтайского бройлера» вырастут до 116 тыс. тонн 6 год.

Также алтайцы достигли успехов 6 выпуске и отгрузке мясных консервов: этой продукции произвели более чем 11 тыс.туб (+60\%). Вырос ассортимент и объемы произбодства колбасной и мясной продукции для детей. 